\title{
Vietnam's Developing Markets: How Do Perceptions And Strategies In The Negotiation Process Differ From The U.S.?
}

Kathryn J. Ready, (Email: kready@winona.edu), Winona State University

Van Dinh, (Email: dinhthanhvan@gmail.com), Hanoi Economics University, Hanoi, Vietnam

\begin{abstract}
Growth in international trade has had a profound effect on executives and managers in their need to better understand differences in effective cross-cultural negotiation skills. The recent opening up of trade with Vietnam points to a need to better understand how the Vietnamese negotiating style differs from the U.S. style as managers are called upon to recruit the best and brightest in an increasingly competitive labor market. In this paper, survey data, taken separately from university students in the U.S. and Vietnam, are used to examine differences in the negotiation process. The results confirmed that cultural differences lead to differences in perceptions and strategies employed in the negotiation process. Theoretical and practical implications for managers involved in negotiations with the Vietnamese as well as directions for future research are discussed.
\end{abstract}

\section{INTRODUCTION}

rowth in international trade has resulted in managers needing to better understand the negotiation process. Negotiation skills not only affect people's performance, satisfaction and quality of work life, they also affect their organization. Effective negotiators can help organizations gain competitive advantages in reducing costs and increasing profits. People in diverse cultures have varying beliefs and perceptions about what negotiation is and how it occurs. They also process negotiations differently and have different preferences for conflict resolution (Lewicki et al, 2006). Studies about negotiation skills across cultures have been conducted to help managers effectively communicate with foreigners (Graham \& Sano, 1989). However, there is a paucity of studies that have been conducted to explore negotiation perceptions and skills with the Vietnamese.

The paper first examines the developing Vietnamese business climate and demonstrates a need for effective negotiation for businesses and for recruiting educated workers. Next, a conceptual framework of cross-culture negotiation is discussed to highlight relevant factors and conflict management styles that may impact the negotiation process. The third section develops the study's hypotheses concerning cross-cultural negotiation differences. The study's method is discussed in the fourth section, and the results are analyzed in section five. The last part of the paper discusses theoretical and practical implications as well as directions for future research.

\section{VIETNAM'S ECONOMIC DEVELOPMENT AND THE NEED TO NEGOTIATE FOR AND WITH EDUCATED EMPLOYEES}

Vietnam is a poor, densely-populated country that has struggled with the ravages of the Vietnam War, the loss of financial support from the old Soviet Bloc, and the inflexibility of a centrally planned communist economy. In 1986, the Vietnamese Communist Party announced the abandonment of the Communist central planning economy and the adoption of a program of market economy restructuring, called "Doi Moi" (Long et al, 2000). The post Doi Moi Vietnamese government encouraged the development of the private economy. By 2004, Vietnam's GDP had reached $\$ 45.4$ billion with per capita income of $\$ 553$ (U.S. State Dept. 2005). Post Doi Moi Vietnam has become one of the 
fastest growing economies in the world averaging about 8\% annual GDP growth rate from 1990 to 1997 and $6.5 \%$ from 1998-2003 (U.S. State Dept. 2005).

Vietnam has been supported in their growth by the huge influx of foreign direct investment (FDI). By the end of 2003, 64 countries and territories had invested in Viet Nam with Asian economies accounting for the majority of these capital inflows (LeProux \& Brooks, 2004). Singapore has been the principal foreign investor with 395 projects and $\$ 7.5$ billion of registered capital, followed by Taiwan, Japan, Korea and Hong Kong (VVG, 2006). In 2005, FDI totaled $\$ 5.8$ billion and in the first 2 months of 2006, Vietnam attracted $\$ 1.32$ billion in FDI (VVG, 2006). The largest investors were S. Korea, Japan, Taiwan and the U.S. In a country with limited infra-structure, Viet Nam has developed a system of industrial zones numbering 76 by the end of 2002. These zones have attracted a high proportion of the total FDI in the country (LeProux \& Brooks, 2004).

Investments from the U.S. dramatically increased after the U.S.-Viet Nam Bilateral Trade Agreement took effect in December of 2001. Bilateral trade between U.S. and Vietnam reached $\$ 6.12$ billion in 2004 (U.S. State Dept, 2005 ) with $\$ 5$ billion in goods being exported to the U.S. Recent legislation has resulted in increased business interest in Vietnam. In December 2003, the Bilateral Air Transport Agreement was negotiated and direct flights between Ho Chi Minh and San Francisco began in December 2004. The accessibility of the Vietnamese markets with the recent infrastructure developments makes it increasingly more advantageous for foreign businesses.

These gains to businesses follow the objectives set forth in the plan of socio-economic development for 2001-2005 originating at the $9^{\text {th }}$ National Congress of the Communist Party of Vietnam in Hanoi in 2001 (The Gioi Publishers, 2004). At this meeting, foundations were established for Vietnam to develop into a modern-industrialized country by 2020. The first part of the plan was to maintain annual GDP growth rate of $7.5 \%$ and create 7.5 million new jobs with only 1.5 million jobs targeted for laborers. Educational goals sought to have $80 \%$ of school-age children enrolled in junior secondary school and $45 \%$ in senior secondary school (The Gioi Publishers, 2004). The focus on education demonstrates the Vietnamese government's goal of providing a capable pool of skilled and educated workers to sustain FDI growth. Currently, Vietnam has more than 200 universities and colleges educating approximately 1 million students a year (Vietnam News, 2006b). However, estimates show that $49.3 \%$ of Vietnam's labor force have only a primary education (Vietnam News, 2006a).

One major disadvantage Viet Nam has is competing with regional neighbors for investment. Doanh (2002) concluded that the high cost of doing business in Viet Nam still represents the main disincentive for foreign enterprises to invest in the country. Yet, the business climate is improving in Vietnam as ASEAN countries have been working to reduce intraregional tariffs and nontariff barriers. Vietnam has pledged to reduce tariffs in all manufactured goods to $0-5 \%$ by 2006 down from an average tariff of $16.52 \%$ in 2002 (MUTRAP, 2002). The improved economic environment leads to more competition in recruiting "the best" Vietnamese employees and in negotiating sound business contracts.

\section{CULTURAL DIFFERENCES INFLUENCE NEGOTIATION STYLES}

Research has shown that differences in cultural backgrounds will distinguish one individual negotiation style from another. Culture affects the range of strategies that negotiators develop as well as the tactics implemented (Salacuse, 1998b). Lewicki et al. (2006) draws on the work of Foster (1992), Hendon and Hendon (1990), Moran and Stripp (1991), and Salacuse (1998a) and develops a model (adapted below) to explain how culture can influence negotiation.

\section{Purpose Of Negotiation}

Purpose of the negotiation varies across cultures. Whereas Americans view negotiations as a competitive process of offers and counteroffers (Foster, 1992), other cultures may view the process as a way to collect information. In Asian cultures, such as Vietnam, the creation of long-term relationships between two parties is more important than the actual deal (Salacuse, 1998a). 


\section{Negotiation Perception}

In the U.S., negotiation had been defined as win-lose or distributive negotiation until the 1970s, when winwin or integrative negotiations came into favor. In integrative negotiation, both parties work to develop a mutually satisfying decision using cooperative effort at mutual problem solving (Levinson et al., 1999). Collaborative bargaining is likely to occur when the negotiators have identified a common goal or objective. A major opportunity in win-win negotiations is the potential to create a situation where all parties achieve or exceed their goals (McGinnis, 2005). The mutually satisfied decision can help build a relationship (Stark \& Flaherty, 2003). Relationships are important in Asian cultures, such as the Vietnamese, and can lead to future negotiations.

\section{Personal Style}

Negotiators may communicate in different ways. Observing negotiators styles can provide insight into the negotiator's background and personality (Salacuse, 1998a). In more formal cultures, such as the Vietnamese culture, negotiators are more likely to address themselves and counterparts by titles, family names and use business cards. In informal cultures, personal and friendly relationships are established quickly; first names are more common. American culture values informality and equality, whereas Asian cultures are more formal.

Table 1: Ten Ways That Culture Influence Negotiation (Adapted From Lewicki Et Al, 2006)

\begin{tabular}{|l|l|c|l|}
\hline Negotiation Factors & \multicolumn{3}{c|}{ Range Of Cultural Response } \\
\hline Purpose of negotiation & Contract & $\leftarrow \rightarrow$ & Relationship \\
Negotiation perception & Distributive & $\leftarrow \rightarrow$ & Integrative \\
Personal styles/protocol & Informal & $\leftarrow \rightarrow$ & Formal \\
Communication styles & Direct, verbally & $\leftarrow \rightarrow$ & Indirect, nonverbally \\
Time sensitivity & High & $\leftarrow \rightarrow$ & Low \\
Group-oriented versus individualism & Collectivism & $\leftarrow \rightarrow$ & Individualism \\
Risk Taking & High & $\leftarrow \rightarrow$ & Low \\
Form of agreements & Specific & $\leftarrow \rightarrow$ & General \\
Emotionalism & High & $\leftarrow \rightarrow$ & Low \\
Negotiators selection & Experts & $\leftarrow \rightarrow$ & Trusted associates \\
\hline
\end{tabular}

\section{Communication Styles}

Hall (1959) explained differences in negotiation across cultures by two different cultural values: (1) communication context and (2) time and space. Hall (1959) argued that cultures will be influenced by whether it's high text communication or low text communication. High-text cultures communicate less directly, and the meaning is conveyed with context. Low-text cultures, in contrast, communicate directly using meaning from words spoken. The Vietnamese and other Asian cultures tend to be more indirect in their negotiation style which Hall (1959) would consider high context. Typically the Vietnamese will try to avoid overt conflict and the expression of anger. They also do not like to say "no" because they feel a direct refusal implies disrespect and interferes with the harmony of the relationship (Vietnam Datacommunication Company, 2001). This indirect way of expressing disapproval may lead others to feel that the proposal is still being considered, when in actuality the Vietnamese have rejected it.

\section{Time Sensitivity}

Hall's (1959) second dimension, time and space, implies cultural differences in managing and scheduling activities. Americans tend to be punctual and concerned with productivity in business situations. This difference in time perceptions may lead to misunderstanding between the parties in the negotiation process. 


\section{Group Oriented Versus Individualism}

Knowing how the other party makes a decision is very important in negotiation. Americans value individualism and are more likely to handle negotiation independently, and take full credit for success. In the Vietnamese culture, consensus building is a key aspect in decision-making (Huynh, 2004).

\section{Risk Taking}

Certain cultures, like the U.S., are willing to take more risk than others when reaching decisions and will many times react more quickly (Hofstede, 1989). Other cultures utilize more time and information in reaching decisions and are not as accepting of risk. The willingness to accept risk can affect the process and outcomes of the negotiation. Negotiators with a low level of risk aversiveness will be open to new approaches and better able to tolerate uncertainties.

\section{Form of Agreements}

Cultural differences affect how a negotiator reaches an agreement. In the United States, agreements are formalized. In Asian cultures, family connections and relationships with friends may impact the negotiation and the method of closing the deal.

\section{Emotionalism}

Individuals across cultures vary in their tendencies to display emotion when negotiating agreements (Salacuse, 1998b). In Asian cultures, individuals are more likely to hide their feelings in negotiation, whereas Americans tend to be more straightforward.

\section{Negotiators Selection}

The criteria used to select negotiators may vary across cultures. Several aspects may be considered such as gender, age, experience, status, and seniority (Lewicki et al, 2006). Americans tend to select negotiators on the basis of ability and experience, whereas Asian cultures, like Vietnam, typically select individuals with higher status. Elders are accorded more respect in the Vietnamese culture and are considered the carriers of tradition, knowledge and wisdom (Huynh, 2004).

\section{INDIVIDUAL CONFLICT RESOLUTION STYLES AND THEIR EFFECTS ON NEGOTIATION STYLES}

Cultural differences impact how negotiators process and resolve conflicts. Thomas and Kilman (1974) identified five different conflict handling modes: competing, collaborating, compromising, accommodating and avoiding. Individuals engaged in distributive negotiations are seeking to "win" the negotiation and are more likely to view negotiations as competition. Individuals that believe in a win-win or integrative style are likely to embrace a collaborative framework resulting in more time and energy in reaching a solution. When issues in the negotiation are perceived as low in importance to one of the parties in the negotiation, that party is likely to accommodate the needs of the other party to maintain the relationship. Compromising is the most common form and is used when negotiators have equal power status dealing with issues of moderate importance or time constraints. Avoiders seek to eliminate conflict and are more likely to walk away from any perceived conflict.

Friedman et al. (2000) concluded that conflict management styles are relatively stable and each individual will have a preferred conflict management style. Similarly, different cultures adopt certain styles more so than others. A collective culture, such as Vietnam, focuses more on the process. They tend to avoid conflict and work to resolve minor issues before they become serious. They are more willing to compromise or collaborate to preserve the party's relationship (Tse et al, 1994; Morris et al, 1998). An individualistic culture, such as the U.S. emphasizes individual achievement and prefers competitive strategies for handling conflict that focus on outcome. 
In addition to cultural differences, gender differences may also influence the preferred negotiation style and outcome of the negotiation process. Two recent large-scale meta-analytic reviews of the literature on gender differences in negotiation have concluded that women behave more cooperatively in negotiation than men (Walter et al, 1998), and that men tend to negotiate better outcomes than women (Stuhlmacher and Walters, 1999). Women are more likely to see a negotiation as one event in a long-term relationship whereas men are more likely to think of it as a "one-shot" deal (Greenhalgh and Gilkey, 1993).

\section{THE STUDY'S HYPOTHESES}

The recent opening up of the Vietnamese markets has created an important need to more fully understand cross-cultural differences in the perceptions and methods of the negotiation process. In order to become an effective negotiator, both Vietnamese and American negotiators should understand their counterparts' negotiation styles. Based on the theoretical analysis of factors that influence an individual's negotiation style, this study examines whether Vietnamese and American students negotiation styles, perceptions and strategies vary due to their differences in cultural backgrounds. Specifically, the hypotheses of this study are as follows:

\section{Hypothesis 1 (Style)}

U.S. students will be more likely to assess winners and losers in the negotiation process due to their cultural backgrounds that support individualism and competition. The Vietnamese culture emphasizes relationships and consensus building and students will have a preference for adopting an integrative approach to negotiation.

\section{Hypothesis 2 (Perceived Effectiveness)}

Despite differences in negotiation style, both Vietnamese and U.S. students will feel that they are effective negotiators and their respective cultures encourage negotiation as a process.

\section{Hypothesis 3 (Perceptions-Gender Differences)}

Both Vietnamese and U.S. students will feel that men are better negotiators than women (3A), and will feel more comfortable negotiating with women than with men (3B). Both Vietnamese and U.S. students will believe they are more successful in negotiations with women than they are with men (3C).

\section{Hypothesis 4 (Process-Strategy)}

Because the U.S. negotiating style has historically been more competitive, U.S. students will be more likely than Vietnamese students to negotiate when they perceive a higher probability of winning (4A). U.S. students will be more likely to set bottom lines (reservation points) before they begin negotiations due to their competitive negotiation style (4B). Due to their emphasis on relationships, Vietnamese students will be more likely to consider the other party's limitations during the negotiation (4C) and will be more likely to compromise with the other party (4D).

\section{Hypothesis 5 (Perceptions-Relationships)}

Due to the importance of preserving relationships, Vietnamese students will feel it's more important to maintain the relationship with the other party than will U.S. students (5A). U.S. students will feel more comfortable negotiating with acquaintances (5B) and with strangers (5C) over the purchase of a vehicle than will Vietnamese students.

\section{Hypothesis 6 (Perceptions-Work Negotiations)}

U.S. students will feel more comfortable negotiating for their first salary (6A) and better working conditions and benefits (6B) than will Vietnamese students due to their competitive negotiating style. 


\section{Hypothesis 7 (Perceptions-Skill Deficiencies)}

Both Vietnamese and American students will feel they need to develop more skills in the negotiation process, however Vietnamese students will view this as more important as a means to preserving relationships.

\section{THE STUDY}

Two samples were used to test the hypotheses in this study. The first sample consisted of 456 responses from students at a mid-western university in the U.S. The second sample consisted of 390 responses from students at a national university in Vietnam. All students who participated in this study were either juniors or seniors majoring in business or economics. The percentages of males and females are equal in the U.S. sample, whereas $34 \%$ are males and $66 \%$ are females in the Vietnamese sample. Students who participated in the study were voluntary. The questionnaires in both samples contained no identifiers and were confidential. American students filled out an online survey in their business classes. The English version was respectively translated into Vietnamese, and then backtranslated to ensure the reliability of the translation. Vietnamese students filled out paper surveys in Vietnam. The Vietnamese paper surveys were then manually entered into SPSS for analysis.

All survey items were assessed on a 1 to 7 Likert scale where $1=$ strongly disagree and $7=$ strongly agree. A single item was used to measure students' negotiation skills and their perceptions toward negotiation. For example, sample items are "In negotiation, there is usually a winner and loser" or "I feel that I am an effective negotiator".

To test the hypotheses, this study used independent-sample t-test for the difference between means in the SPSS software. An assumption of equal variances using Levene's F-test was conducted. The test revealed that there were unequal variances between the two samples. The results in the study are reported under the assumption of unequal variances.

\section{RESULTS}

Table 1 reports the means, standard deviations, t-test and $\mathrm{p}$ values comparing the Vietnamese and U.S. samples. All the means for each measure in both U.S. and Vietnamese samples varied from 3 to 6 , indicating that there are differences in negotiation styles, process and perceptions about negotiation. The specific results for hypothesis testing are as follows:

\section{Perceptions Of Negotiation Style And Perceived Effectiveness}

Thompson (1990) concluded that negotiators in North America considered negotiation as being fundamentally distributive. In his survey, Salacuse (1998b) concluded that the Chinese and other Asian cultures focused on win-win negotiation. We do find cultural differences in the perceptions of the negotiation process. Hypothesis 1 suggests that Vietnamese students are significantly more likely than U.S. students ( $p<.001)$ to agree that there are winners and losers in negotiations. This finding is different from what we had anticipated and may be due to the recent emphasis in the U.S. on integrative negotiations. Recent examples in the press demonstrate the need for joint efforts in negotiations. For example, General Motors and Northwest Airlines are negotiating ways with their unions to control costs to avoid bankruptcy.

Hypothesis 2 suggests that both U.S. and Vietnamese students feel that they are effective negotiators, however U.S. students are significantly more confident than Vietnamese students in their negotiation skills ( $\mathrm{p}<.001$ ). Both American and Vietnamese students believe their cultures support negotiation, however this perception is significantly higher among U.S. students $(\mathrm{p}<.05)$.

\section{Perceptions Of Gender Differences In Negotiation Process}

Hypothesis 3a suggests that neither Vietnamese nor U.S. students feel that men are better negotiators than women. U.S. students exhibited a significantly higher disagreement in this belief than did Vietnamese students 
$(\mathrm{p}<.001)$. Hypothesis $3 \mathrm{~b}$ shows that Vietnamese students are more comfortable than U.S. students in negotiating with women $(\mathrm{p}<.001)$. In hypothesis $3 \mathrm{c}$, U.S. students indicate that they are not more successful in negotiations with women than with men, whereas Vietnamese students are more ambivalent $(\mathrm{p}<.001)$. This finding runs contrary to previous studies on gender differences in negotiations and may be due to students' limited experience in real world business negotiations or the "safe" environment of the college classroom in which they were completing the survey.

\section{Negotiation Process - Strategy}

There are significant differences in risk between Vietnamese and U.S. students. In hypothesis 4a, Vietnamese students indicate that they are more likely to negotiate only when they feel there is a high probability of winning, while U.S. students indicate more uncertainty and may accept more risk and negotiate even when they may not win. It is a common tactic in negotiation to learn as much as possible about the other party before negotiations begins (Graham \& Sano, 1989). Thorough preparation and identification of goals, options, and priorities is critical in a negotiation. Once these are identified, effective negotiators develop strategies to meet those goals (Stark \& Flaherty, 2003). In hypothesis $4 \mathrm{~b}$, both Vietnamese and U.S. students indicate a willingness to develop strategies by setting bottom lines before they begin negotiating, however Vietnamese students indicate significantly more willingness to utilize this strategy $(\mathrm{p}<.001)$. Hypothesis $4 \mathrm{c}$ shows that both Vietnamese and American students will consider the other parties' limitations during the negotiation, but Vietnamese students indicate a significantly higher level of willingness to do so $(p<.001)$. This willingness is expected due to Vietnam's collectivist cultural background. In hypothesis $4 \mathrm{~d}$, both U.S. and Vietnamese students indicate that compromise is important in negotiations with no significant differences between the groups.

\section{Perceptions Of Relationships In Negotiation Process}

Both U.S. and Vietnamese students indicate that maintaining relationships is important in the negotiation process as shown in hypothesis $5 \mathrm{a}$. Hypotheses $5 \mathrm{~b}$ and $5 \mathrm{c}$ show that both Vietnamese and American students feel slightly comfortable negotiating with either acquaintance or strangers over the purchase of a used vehicle. U.S. students indicated that they are significantly more comfortable with either of these negotiations than are Vietnamese students $(\mathrm{p}<.001)$. An interesting finding is that U.S. students prefer to negotiate with strangers over one time purchases of a used vehicle rather than acquaintances (means $=5.5$ and 4.71 , respectively). This demonstrates the importance of relationships in negotiations by U.S. students and supports research that has concluded that parties may sacrifice their own preferences in order to preserve the relationship (Barry and Oliver, 1996).

\section{Perceptions Of Salary And Benefits Negotiations}

Understanding how business students will negotiate about salary and benefits in their first job is important to managers recruiting the most talented employees in a competitive labor market. Effective negotiation should lead to higher salary and benefit levels. Hypothesis $6 \mathrm{a}$ and $6 \mathrm{~b}$ show that both Vietnamese and American students feel only slightly comfortable negotiating for their first salary and better working conditions and benefits. Vietnamese students are more comfortable negotiating for salary than U.S. students ( $<<.001$ ), however U.S. students are more comfortable negotiating for better working conditions and benefits than are Vietnamese students $(\mathrm{p}<.001)$. Both groups of students indicate that they are more comfortable negotiating for better working conditions and benefits than they are negotiating for salary.

\section{Perceptions Of Needed Skill Development}

Negotiation skills are gradually developed by training and experience (Levinson et al, 1999). Hypothesis 7 reveals that both Vietnamese and American students feel they need to develop more skills in negotiating, however Vietnamese students indicate a greater need for negotiation skill training than do U.S. students ( $\mathrm{p}<.001)$. This finding may also be culturally based due to the importance of preserving relationships in the Vietnamese culture. 


\section{DISCUSSION AND IMPLICATION}

The findings in this study show the importance of culture and its implication on the negotiation process. In high context and collectivist cultures such as Vietnam, it is suggested that negotiation is relationship-oriented. The implication is that it is collaborative and will lead to some mutual satisfaction. In a low context and highly individualistic U.S. culture, negotiators focus more on results. These cultural differences are supported in several areas. Vietnamese students are more likely to consider the other party's limitations during the negotiation thereby preserving relationships in the negotiation. U.S. students may be more willing to accept risk than Vietnamese students and may negotiate even when they do not feel they have a high probability of winning. U.S. students are also significantly more likely than Vietnamese students to indicate that they grew up in a family culture that encouraged negotiation indicating the competitive nature of the U.S. culture.

On the other hand, survey results show that American and Vietnamese students have certain perceptions before they negotiate that do not necessarily support cultural norms. American students appear more open than Vietnamese students to a win-win solution approach and do not view negotiation as a win/loss proposition. Vietnamese students appear to be more accepting of distributive approaches than cultural norms may typically lead us to believe. Further, Vietnamese students are significantly more likely than U.S. students to consider their bottom line before they begin negotiating and will feel more comfortable negotiating for their starting salary than will U.S. students. However, both groups are more comfortable negotiating for benefits and working conditions than they are negotiating for salary.

To enter the Vietnamese market, American managers will negotiate not only with foreign businesses and customers, but also with prospective employees via the recruiting and hiring process. Because the findings suggest that negotiation style is influenced by cultural norms, this information is critical in hiring and training prospective cross-cultural negotiators. Companies in Vietnam and the U.S. should provide assistance to improve negotiation skills and experiences for its employees. Companies might hold cross-culture training sessions for employees before entering a foreign market. Vietnamese, as well as U.S. students, indicate a need for more negotiation training. Inhouse negotiation skills seminars or university courses focusing on negotiation skills would be useful in this respect.

The findings in this study indicate some important practical information for both Vietnamese and American managers that are involved in conducting business in Vietnam. In international negotiations, parties have different values, beliefs and backgrounds influenced by cultural differences. More information about cross-cultural differences in negotiation is needed. While it is helpful to use cultural dimensions as guidelines for international negotiation, they should not be considered as absolute measures to prejudice individuals about a specific culture as we have found in this study.

\section{LIMITATIONS AND CONCLUSIONS}

Emerging as one of Asia's newly industrializing countries, Vietnam represents a wonderful opportunity for business growth. A fast growing population of over 84 million (CIA, 2006) and more than a $90 \%$ literacy rate among those under 30 years of age strengthen Vietnam's move toward a market economy. The market liberalization process was further enhanced by the entrance to the Association of Southeast Asian Nations (ASEAN) and the recent bi-lateral trade agreement with the U.S. As business increases, differences in values and beliefs create challenges for both Vietnamese and American managers in negotiation across cultures. This study aided in comparing differences between Vietnamese and American perceptions about negotiation skills, processes and strategies employed.

Some limitations exist in this study. First, the study used student samples in both Vietnam and the U.S. Although students in this study were those who reported having some work experiences and negotiation participation, it may not be accurate to generalize those students' attitudes and expectations to the whole population. Second, because the measurement of perceptions and negotiation skills was based on single items, it may not fully capture the concepts or yield precise results. Despite these limitations, this paper provides some understandings about the Vietnamese and American perceptions of negotiation and perceived negotiation skills and highlights cultural 
differences. An understanding of these differences is important for all businesses and managers who are and will be doing business in Vietnam.

Table 2: Negotiation Perceptions And Strategies

\begin{tabular}{|c|c|c|c|c|c|}
\hline Negotiation Item Measures & $\begin{array}{c}\text { Country } \\
\text { Comparisons }\end{array}$ & $\mathbf{N}$ & Mean & $\begin{array}{l}\text { Std. } \\
\text { Dev. }\end{array}$ & $\begin{array}{l}\text { T test } \\
\mathbf{P} \\
\text { value }\end{array}$ \\
\hline $\begin{array}{l}\text { 1. Perceptions of style: In negotiation, there is usually a winner and a } \\
\text { loser. }\end{array}$ & $\begin{array}{c}\text { U.S. } \\
\text { Vietnam }\end{array}$ & $\begin{array}{l}457 \\
388\end{array}$ & $\begin{array}{l}3.66 \\
4.35\end{array}$ & $\begin{array}{l}1.497 \\
1.966\end{array}$ & $\begin{array}{r}-5.74 \\
.000\end{array}$ \\
\hline $\begin{array}{l}\text { 2a. Perceptions of Effectiveness: I feel that I am an effective } \\
\text { negotiator. }\end{array}$ & $\begin{array}{c}\text { U.S. } \\
\text { Vietnam }\end{array}$ & $\begin{array}{l}455 \\
378 \\
\end{array}$ & $\begin{array}{l}5.08 \\
4.67\end{array}$ & $\begin{array}{l}1.258 \\
1.438\end{array}$ & $\begin{array}{l}4.33 \\
.000\end{array}$ \\
\hline $\begin{array}{l}\text { 2b. Perceptions of culture: I grew up in a family culture that } \\
\text { encourage negotiation. }\end{array}$ & $\begin{array}{c}\text { U.S. } \\
\text { Vietnam }\end{array}$ & $\begin{array}{l}457 \\
378 \\
\end{array}$ & $\begin{array}{l}4.53 \\
4.28 \\
\end{array}$ & $\begin{array}{l}1.522 \\
1.645\end{array}$ & $\begin{array}{l}2.29 \\
.022 \\
\end{array}$ \\
\hline $\begin{array}{l}\text { 3a. Perceptions of Gender Differences: In general, men are better } \\
\text { negotiators than women. }\end{array}$ & $\begin{array}{c}\text { U.S. } \\
\text { Vietnam }\end{array}$ & $\begin{array}{l}456 \\
380\end{array}$ & $\begin{array}{l}3.01 \\
3.64\end{array}$ & $\begin{array}{l}1.551 \\
1.881\end{array}$ & $\begin{array}{r}-5.29 \\
.000\end{array}$ \\
\hline $\begin{array}{l}\text { 3b. Perceptions of Gender Differences: I am more comfortable } \\
\text { negotiating with women than I am with men. }\end{array}$ & $\begin{array}{c}\text { U.S. } \\
\text { Vietnam }\end{array}$ & $\begin{array}{l}454 \\
381\end{array}$ & $\begin{array}{l}3.80 \\
4.39\end{array}$ & $\begin{array}{l}1.487 \\
1.654\end{array}$ & $\begin{array}{r}-5.44 \\
.000\end{array}$ \\
\hline $\begin{array}{l}\text { 3c. Perceptions of Gender Differences: I am more successful in } \\
\text { negotiations with women than I am with men. }\end{array}$ & $\begin{array}{c}\text { U.S. } \\
\text { Vietnam }\end{array}$ & $\begin{array}{l}456 \\
372 \\
\end{array}$ & $\begin{array}{l}3.75 \\
4.03\end{array}$ & $\begin{array}{l}1.373 \\
1.553\end{array}$ & $\begin{array}{r}-2.74 \\
.006\end{array}$ \\
\hline $\begin{array}{l}\text { 4a. Process-Strategy: I will only negotiate when I feel there is a high } \\
\text { probability of winning. }\end{array}$ & $\begin{array}{c}\text { U.S. } \\
\text { Vietnam }\end{array}$ & $\begin{array}{l}454 \\
374 \\
\end{array}$ & $\begin{array}{l}3.94 \\
4.44\end{array}$ & $\begin{array}{l}1.413 \\
1.713\end{array}$ & $\begin{array}{l}-4.65 \\
.000\end{array}$ \\
\hline $\begin{array}{l}\text { 4b. Process-Strategy: I determine my bottom line position before I } \\
\text { begin negotiating. }\end{array}$ & $\begin{array}{c}\text { U.S. } \\
\text { Vietnam }\end{array}$ & $\begin{array}{l}454 \\
382 \\
\end{array}$ & $\begin{array}{l}5.05 \\
5.57\end{array}$ & $\begin{array}{l}1.327 \\
1.575\end{array}$ & $\begin{array}{r}-5.25 \\
.000\end{array}$ \\
\hline $\begin{array}{l}\text { 4c. Process-Strategy: I continually consider the other party's } \\
\text { limitations during the negotiation. }\end{array}$ & $\begin{array}{c}\text { U.S. } \\
\text { Vietnam }\end{array}$ & $\begin{array}{l}455 \\
380\end{array}$ & $\begin{array}{l}4.57 \\
4.91\end{array}$ & $\begin{array}{l}1.207 \\
1.452\end{array}$ & $\begin{array}{r}-3.66 \\
.000\end{array}$ \\
\hline $\begin{array}{l}\text { 4d. Process-Strategy: It is important to compromise with the other } \\
\text { party in negotiation. }\end{array}$ & $\begin{array}{c}\text { U.S. } \\
\text { Vietnam }\end{array}$ & $\begin{array}{l}457 \\
383 \\
\end{array}$ & $\begin{array}{l}5.32 \\
5.23 \\
\end{array}$ & $\begin{array}{l}1.253 \\
1.646 \\
\end{array}$ & $\begin{array}{l}.844 \\
.399 \\
\end{array}$ \\
\hline $\begin{array}{l}\text { 5a. Throughout the negotiating process, I am concerned with } \\
\text { maintaining relationships with the other party. }\end{array}$ & $\begin{array}{c}\text { U.S. } \\
\text { Vietnam }\end{array}$ & $\begin{array}{l}456 \\
379 \\
\end{array}$ & $\begin{array}{l}5.08 \\
5.26\end{array}$ & $\begin{array}{l}1.220 \\
1.499\end{array}$ & $\begin{array}{r}-1.92 \\
.055\end{array}$ \\
\hline $\begin{array}{l}\text { 5b. Perceptions of Relationships: I would feel comfortable } \\
\text { negotiating with an acquaintance over the purchase of a used vehicle. }\end{array}$ & $\begin{array}{c}\text { U.S. } \\
\text { Vietnam }\end{array}$ & $\begin{array}{l}455 \\
382\end{array}$ & $\begin{array}{l}4.71 \\
4.36\end{array}$ & $\begin{array}{l}1.458 \\
1.629\end{array}$ & $\begin{array}{l}3.35 \\
.001\end{array}$ \\
\hline $\begin{array}{l}\text { 5c. Perceptions of Relationships: I would feel comfortable } \\
\text { negotiating with a stranger over the purchase of a used vehicle. }\end{array}$ & $\begin{array}{c}\text { U.S. } \\
\text { Vietnam }\end{array}$ & $\begin{array}{l}457 \\
378\end{array}$ & $\begin{array}{l}5.52 \\
4.34 \\
\end{array}$ & $\begin{array}{l}1.413 \\
1.769\end{array}$ & $\begin{array}{l}10.7 \\
.000\end{array}$ \\
\hline $\begin{array}{l}\text { 6a. Perceptions-Salary \& Benefits: I would feel comfortable } \\
\text { negotiating for my starting salary in my first professional job. }\end{array}$ & $\begin{array}{c}\text { U.S. } \\
\text { Vietnam }\end{array}$ & $\begin{array}{l}455 \\
379 \\
\end{array}$ & $\begin{array}{l}4.12 \\
4.58 \\
\end{array}$ & $\begin{array}{l}1.563 \\
1.648 \\
\end{array}$ & $\begin{array}{r}-4.12 \\
.000 \\
\end{array}$ \\
\hline $\begin{array}{l}\text { 6b. Perceptions-Salary \& Benefits: I would feel comfort. negotiating } \\
\text { for better working conditions \& benefits (laptop computers etc.) with } \\
\text { my company. }\end{array}$ & $\begin{array}{c}\text { U.S. } \\
\text { Vietnam }\end{array}$ & $\begin{array}{l}454 \\
380\end{array}$ & $\begin{array}{l}5.06 \\
4.78\end{array}$ & $\begin{array}{l}1.208 \\
1.585\end{array}$ & $\begin{array}{l}2.88 \\
.004\end{array}$ \\
\hline $\begin{array}{l}\text { 7. Needed Skills: I feel that I need to develop more skills in } \\
\text { negotiating. }\end{array}$ & $\begin{array}{c}\text { U.S. } \\
\text { Vietnam }\end{array}$ & $\begin{array}{l}455 \\
377 \\
\end{array}$ & $\begin{array}{l}5.08 \\
5.66\end{array}$ & $\begin{array}{l}1.508 \\
1.568\end{array}$ & $\begin{array}{r}-5.39 \\
.000 \\
\end{array}$ \\
\hline
\end{tabular}

\section{REFERENCES}

1. Barry, B. and R. L. Oliver (1996). Affect in dyadic negotiation: A model and propositions. Organizational Behavior and Human Decision Processes, 67, 127-43.

2. Central Intelligence Agency (2006). The World Fact Book 2006. Washington, D.C.

3. Doanh, L. D., (2002). Foreign Direct Investment in Vietnam: Results, Achievements, Challenges and Prospects. Paper presented at the conference on Foreign Direct Investment, 16-17 August, Hanoi.

4. Foster, D. A. (1992). Bargaining across borders: How to negotiate business successfully anywhere in the world. New York: McGraw-Hill.

5. Friedman, R., Tidd, S., Currall, S., and Tsai, J. (2000) What Goes Around Comes Around: The Effects of Conflict Style on Work Environment and Stress, International Journal of Conflict Management, 11, 1: 32-55.

6. Graham, J. L. and Y. Sano (1989). Smart Bargaining: Doing Business with the Japanese. New York: Harper Business. 
7. Greenhalgh, L. and R. W. Gilkey (1993). The effect of relationship orientation on negotiator's cognitions and tactics. Group Decision and Negotiation. 2: 167-186.

8. $\quad$ Hall, E. T. (1959). The Silent Language. New York: Anchor Press.

9. Hendon, D. W. and R. A. Hendon (1990) World-class negotiating: Dealmaking in the global Marketplace. New York: John Wiley and Sons.

10. Hofstede, G. (1989). Cultural predictors of national negotiation styles. In F. Mauntner-Markhof (Ed.), Processes of international negotiations (pp. 193-201). Boulder, CO: Westview Press.

11. Huynh, Dinh Te. (2004). Attitude toward the self, Massachusetts Legal Service, Diversity Coalition. Status of the individual. Obtained on March 12, 2006 at http://www.diversitycoalition.org/vietnamese_culture?wid $\equiv 70 \&$ func $=$ view \& templateId $=1$

12. LeProux, V. and D. H. Brooks (2004). ERD Working Paper Series No. 56. Vietnam: Foreign Direct Investment an Postcrisis Regional Integration, Asian Development Bank, Manila, Phillipines.

13. Levinson, J. C., M. S. A., Smith, and O.R. Wilson (1999). Guerilla negotiating: Unconventional Weapons and Tactics to Get What you Want. New York: John Wiley.

14. Lewicki, R., D. Saunders, and B. Barry, (2006). Negotiation. McGraw-Hill, Irwin: Boston, MA.

15. Long, Lynellyn D., Hung, Le Ngoc, Truitt, Allison, Mai, Le Thi Phuong, and Anh, Dang Nguyen (2000). Changing Gender Relations In Vietnam's Post Doi Moi Era. Hanoi, Vietnam: Population Council

16. McGinnis, M. A., (2005). Advanced Negotiations: Lessons from the International Arena, $90^{\text {th }}$ Annual International Supply Management Conference, May, Penn State New Kensington, PA. Obtained at mam47@psu.edu on January 16, 2006.

17. Moran, R. T. and Stripp, W. G. (1991). Dynamics of successful international business negotiations. Houston, TX: Gulf Publishing.

18. Morris, M. W., K. Y. Williams, K. Leung, R. Larrick, M. T. Mendoza, D. Bhatnagar, J. Li, M. Kondo, J. Luo, and J. Hu, (1998), Conflict Management Style: Accounting for Cross-National Differences, Journal of International Business Studies, 29, 4, 729-47.

19. MUTRAP (2002). The FACTOM Model: FED Attraction Comparison and Trade Openness Measure. Multilateral Trade Policy Assistance Program, European Commission, Vietnam.

20. Quynh, P., H. Nguyen, and T. Bui (2002). A Study of Trade, Foreign Direct Investment and Labour in Vietnam. Mekong Economics, Hanoi.

21. Salacuse, J. W. (1998). So What's the Deal Anyway? Contracts and relationships as Negotiating Goals, Negotiation Journal, 14(1), 5-12.

22. Salacuse, J. W. (1998). Ten Ways that Culture affects negotiating style: Some Survey Results, Negotiation Journal, July, 221-240.

23. Stark, P. and Flaherty, J. (2003). The Only Negotiating Guide You'll Ever Need: 101 Ways to Win Every Time in Any Situation. Random House: New York NY.

24. Stuhlmacher, A. F., and Walters, A. E. (1999). Gender differences in negotiation outcomes: A metaanalysis. Personnel Psychology, 52, 653-77.

25. The Gioi Publishers (2004), Vietnam Today, Hanoi, Vietnam.

26. Thomas, K. W. and R. H. Kilman (1974). Thomas-Kilman Conflict Mode Survey. Tuxedo, NY: Xicom.

27. Thompson, L. (1990). Negotiation Behavior and Outcomes: Empirical Evidence and Theoretical Issues, Psychological Bulletin, 108, 515-32.

28. Tse, D. K., J. Francis, and J. Walls, (1994). Cultural Differences in Conducting Intra- and Inter-Cultural Negotiations: A Sino-Canadian Comparison, Journal of International Business Studies, 25, 537-55.

29. U.S. State Dept. (2005), Background Note: Vietnam. Obtained at http://www.state.gov/r/pa/ei/bgn/4130.htm on Feb. 20, 2006.

30. Vietnam Datacommunication Company. (2001). Doing Business in Vietnam, 21 Feb. 2006 http://siteresources.worldback.org/INTRANETTRADE/Resources/WBI-Training/vietFIP_dat.pdf

31. Vietnam News, Skilled Workforce Becomes a Priority (6/21/06). Obtained at http://vietnamnews.vnagency.com.vn/showarticle.php?num=02LAB210606 on 6/30/06.

32. Vietnam News, University Entrance Exams Draws 1.7 million students (6/14/06). Obtained at http://vietnamnews.vnagency.com.vn/showarticle.php?num=03EDU040706 on 7/1/06.

33. VVG Economic Indicators (2006). Obtained at http://www.vvg-vietnam.com/economics_cvr.htm\#Foreign Capital Investment on June 30, 2006. 
34. Walter, A. E., Stuhlmacher, A. F., and Meyer, L. L. (1998). Gender and negotiator competitiveness; A metaanalysis. Organizational Behavior and Human Decision Processes, 76, 1-29.

\section{NOTES}




\section{NOTES}

